\title{
Examining the Role of Facebook in the Dissemination of Hate Messages over the Agitation for Biafra in
} Ikeja, Lagos

\author{
Olupohunda Bayo Festus and Ogbu, S. U., , Ph.D. \\ School of Media and Communication, Pan Atlantic University, KM 52 Lekki-Epe Expressway, \\ Ibeju-Lekki, Lagos; abayomi.olupohunda@pau.edu.ng \\ Corresponding author: sogbu@ pau.edu.ng
}

Received 22 August 2019

Accepted 1 September 2019

Published 2 October 2019

\begin{abstract}
In Nigeria, during the agitation for Biafra by the Nnamdi Kanu-led Indigenous People of Biafra between 2013 and 2017, the role of Facebook in the dissemination of hate messages by the protagonists and those in opposition to the agitation raised concern about the role of social media as a tool for the spread of hate messages. It is against this background that this research was designed to evaluate the role of Facebook in the spread of hate messages over the agitation for the separate state of Biafra. The study adopted the exploratory design and the mix method approach; both quantitative and qualitative methods were employed. For the quantitative data, 400 questionnaires were administered on purposively sampled respondents. The surveys were analyzed using simple percentages and frequency distribution. Also, content analysis of some purposively selected Facebook messages was carried out. In the end, the research found that hate messages were propagated through Facebook using six major channels during the agitation for Biafra between 2013 and 2017. They include; Facebook Personal Profiles, Status Updates and Wall Postings, Facebook Group Chats, Facebook Video Uploads, Individual Comments and Likes, Video Shares and Reposts, and sharing of articles and links to other social media platforms. In line with its findings, the research recommended that Facebook should review its community standards and policies on postings of hate messages through its medium and also strengthen its regulatory mechanisms to ensure that it does not provide a platform anymore for propagators of hate messages in Nigeria and around the world.
\end{abstract}

Keywords: Facebook, Hate message, Biafra, Nnamdi Kanu, Communication, New Media Technologies, Discrimination

\section{Introduction}

The emergence of social media is altering the nature of communication. Its rapid development has led to the evolvement of societal culture that has redefined the way we interact and source for information. Although social media platforms are created for accessible communication for family and friends, they have since expanded to the rest of the world as platforms to reflect personal and group views on economic, political and social issues (Kinyamu, 2012). This divergence has created a society of interactions built on mutual collective sentiments, which may or may not be healthy for community and stakeholders, depending on the kind of views and how they are shared.

Unfortunately, the democratic nature of social media has led to a cyber revolution through which information has become weaponized for the promotion of misinformation, insurgency, propaganda, violation of human rights, false sensitization, victimization, and cyber bullying, and particularly for the spread of hate messages. The threat posed by the amplification of hate messages on social media platforms is not new. Advocates for human rights have for long drawn attention to the damage being caused by hate messages and have in the last few decades been calling for some regulatory measures to avert future disaster. The phenomenon of 'hate message' has generated heightened interest due to the freedom by users to share content with little or no supervisory control. This concern was most noticeable during the agitation for Biafra by the Nnamdi Kanu led Indigenous People of Biafra (IPOB) between 2013 and 2017 on social media platforms.

Facebook is one of such social media channels that was used by the IPOB for its campaign because the platform enjoys high membership among Nigerians following the increasing rate of internet penetration. Facebook was actively used to spread dangerous messages during the agitation by both Biafra supporters and those in opposition, mostly from the Hausa-Fulani ethnic group and other ethnic groups in Nigeria. The spread of hate messages on Facebook was mainly driven by ethnic sentiments against the Igbo people of eastern Nigeria and also by the unpleasant attacks of the Igbos on other ethnic groups who were not in support of their agitation for secession (NSRP, 2017). It was easy for all the parties to spread hate messages through Facebook because the platform has some features that allow users to share updates through personal profiles. Group profiles also allow for those with the same ideology to join open or closed groups. These 
features enable users to comment, share, and post messages which may reflect their biases. These messages can be xenophobic and politically charged, and they often attack ethnic groups and other affiliations. It is against the backdrop that this study examines the role of Facebook in the dissemination of hate messages over the agitation for Biafra among the residents of Ikeja local government area in Lagos state.

\section{Statement of Problem}

Although the legislative arm proposed a law that will criminalize posting of offensive materials online, it still did not deter people from using social media for this purpose because online platforms are devoid of absolute control. The power of social media and the consequences of its malicious application cannot be overemphasized. So far, hate messages, spread online is becoming one of the most powerful tools for the spread of violence. Facebook has provided a fertile ground to facilitate its dissemination (Molnar, 2012).

Furthermore, the mainstream media, on the other hand, enforce media laws and journalistic codes that govern and regulate the dissemination of information. In this regard, there is some measure of control over issues such as hate messages. During the Nnamdi Kanu arrest saga, most reportage by the conventional mediamaintained neutrality to avoid inciting the public to violent action. Social media users, however, have no journalistic background and operate without subjection to any particular code.

In its report, titled Monitoring Online Hate Speech, CITAD (2017), conducted a survey using a programmed online medium to watch and push back hate and unsafe messages online as well as tracking identified online platforms spreading hate messages. The report revealed that 60.3 percent of dangerous messages recorded came from Facebook, 5.9 percent from bulletins, and four percent from blogs monitored during the period. The report also revealed that 35.2 percent of the hate messages surveyed insult people for their faith; attack people because of their ethnic, linguistic background; or convey hatred against people because of where they come from. In the light of the above, and given the impact of online hate messages in a multi-ethnic society like Nigeria, this study seeks to evaluate the role of Facebook in the dissemination of hate messages over the agitation for Biafra during its resurgence with the Nnamdi Kanu led Indigenous People of Biafra between 2013 and 2017. Hate message spread online through Facebook is also said to have the capacity to spread quickly, given the toxic and viral nature of the messages. The study also seeks to examine the spread of hate messages on other social media platforms aside from Facebook. Primarily, the research examined the proliferation of hate messages on Facebook by both the agitators of Biafra and others opposed to the agitation.

\section{Research Objectives}

This research outlines three specific objectives for the study:

1. To find out the extent of access to Facebook by residents of Ikeja during the agitation for Biafra between 2013 2017

2. To find out how Facebook was used for the dissemination of hate messages by residents of Ikeja during the period under review

3. To find out other social media platforms Ikeja residents employed in the propagation of hate messages during the agitation for Biafra besides Facebook.

\section{Conceptual Framework}

\section{Overview of Facebook}

Facebook was established in February 2004 by Mark Zuckerberg as a platform meant exclusively for Harvard University students. Immediately after, the platform opened up to other students with a customized Harvard official mail account. In 2005 and 2006, Facebook extended to high school students nationwide and people in the workforce and finally, to all users of the internet. In 2017, Facebook was ranked as the most visited website globally and as the most popular website worldwide amassing 1.4 billion daily users for December 2017 and 2.13 billion monthly frequent users as of December 31, 2017 (Statista, 2018). The data showed that more than half of the users visit Facebook every day and spend about 20 minutes averagely daily. Like many social media sites, Facebook allows users to enter personal bio, including sexual category, date, and place of birth, belief systems in politics and religion, mail and contact address, marital status, hobbies and choice of music and movies, educational information and profile picture.

After inputting their profile, users are encouraged to seek out other Facebook users to whom they can also send a request. That is done by searching for existing users of Facebook or by asking their friends to create accounts with the platform. As soon as the offer is accepted, the profile of the two friends and their other friends can be added as friends too by the user. That enables the user to navigate networks by surfing a list of potential friends' profiles. By so doing, friendships snowballed on Facebook (Walther, Kim, Heide \& Tong, 2008). These features form the bedrock of the platform and the reason why it draws millions of subscribers around the world.

Profiles on the platform also include two main types of communication messaging features. An interactive system, which is equivalent to a mail service, and an open network called "The Wall," where Facebook users post comments that the owner of the profile that can see, Typically, "The Wall" has small messages that reveal feelings and universal activities among 'friends,' or draw awareness to other sites or events. To help users update their friends on their social activities, Facebook has two characteristic features: "News Feed," which shows on the main page of consumer and "small feeds," which appear in the user's profile. There are also tailored streams of news flow throughout the day, which are the updates from 'friends.'

As a result, every time a user signs in, he or she gets the current topics in his or her home page. "Mini-Feed" is connected to news stream except that it is woven around a single user. Facebook's "Mini-Feed" displays new happenings in a user's account and what has transformed. Facebook allows users to remove their mini-feed and stories. Facebook users also have the power to regulate what appears on their timeline and what they share. Facebook groups," is the most popular feature of Facebook. The feature enables users to form and belong to groups depending on mutual interests. The "groups" show users the groups that their friends have belonged to in recent times. This feature represents a significant part of the community and is used by many to create political platforms on Facebook.

\section{Facebook in Nigeria}

Internet usage in Nigeria has increased in the last decade. Statistics reveal that Facebook remains a popular social media platform among Nigerians, with 16 million subscribers visiting the platform monthly (Kazeem, 2016). Nigeria is also reputed to be Facebook's biggest market in Africa. According to data released by Facebook 
in 2017, there are 12 million users in South Africa. Kenya has 4.5 million. Nigeria is one of the countries with the highest smartphone usage in Africa, and the number is expected to expand as smartphone penetration is expected to attain 95 million by the year 2019 (Kazeem, 2016).

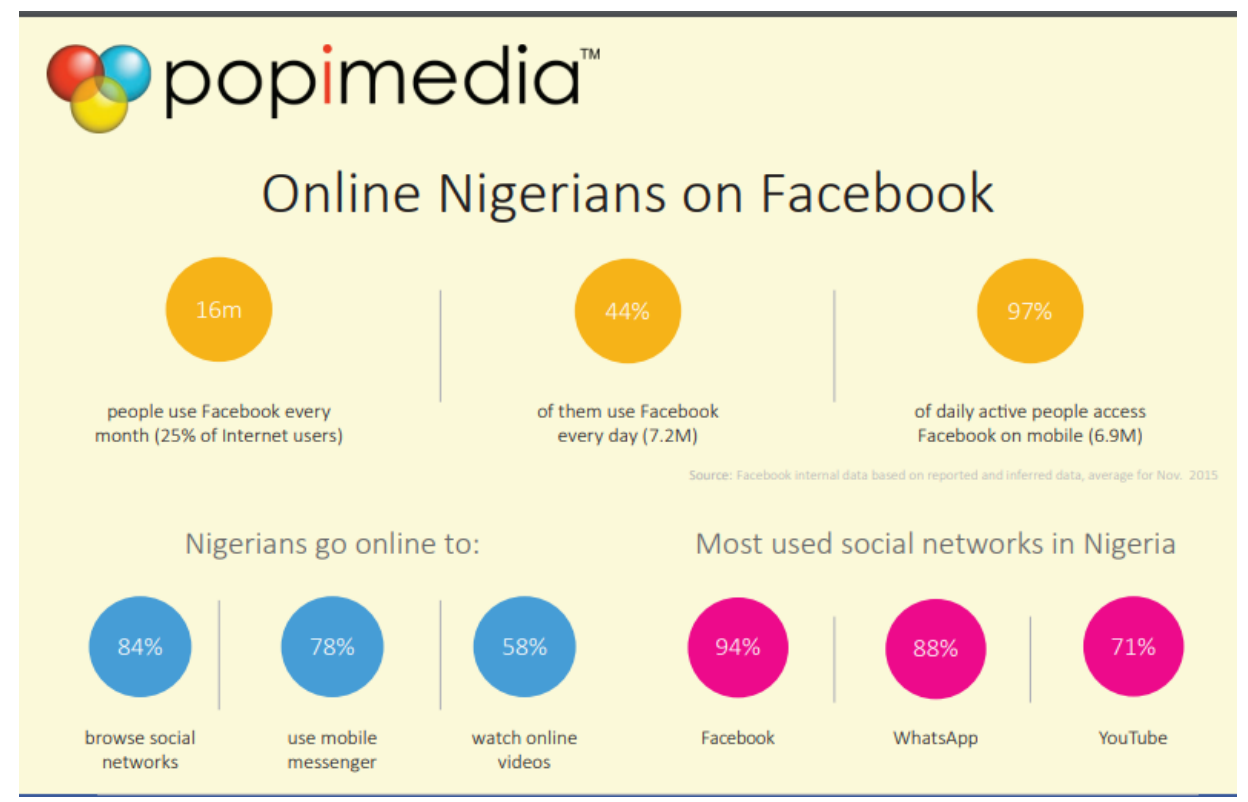

Source: Popimedia.com 2017

Figure 2.2: Facebook users in Nigeria

Facebook statistics also showed that 7.2 million users visit its platform, with about $97 \%$ of them using the platform via portable platforms. The fast growth of mobile and internet usage in Nigeria is creating advantages and revenue for the platform in the country. The importance of Facebook is shown by the visit to Nigeria in 2016 by its founder Mark Zuckerberg.

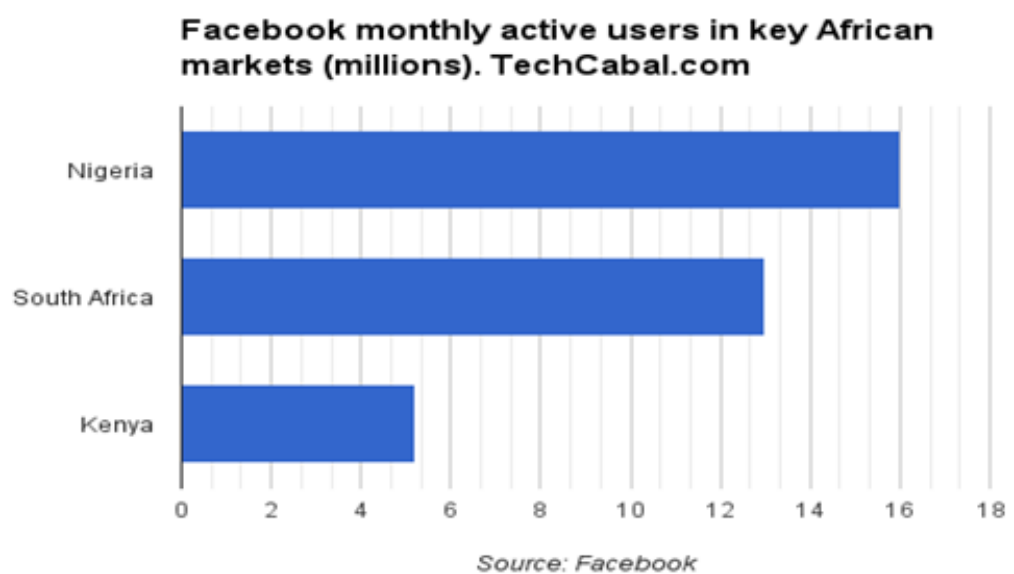

Source: Techcabal 2017

Figure2.3: Nigeria leads Africa in number of active Facebook users

According to Nunu Ntshingila, Facebook CEO for Africa, "Nigerians are urbane social media users, and this superiority is expanding fast that Nigerians are moving beyond entrepreneurship. A major challenge will be to develop a viable market for Facebook users in the country" (Mohapi, 2017).

\section{The Concept of Hate Speech}

Elliot, Chuma, Gendi \& Patel ( 2016), defines hate speech as messages that spread, provoke, sanction or justify ethnic hate, racism, prejudice or other types of hate hinged on bigotry, including bias expressed by violent xenophobia, and resentment towards people of minority and immigrant origin. "The United Nations International Committee on the Elimination of Racial Discrimination explains hate message as a type of message that discards the nucleus of basic human rights values of self-esteem and egalitarianism and seeks to denigrate the status of the human person and groups in a society" (UNHRC, 2017).
Hate messages are disseminated through hate speeches that occur when individuals and groups of people from diverse social, religious, ethnic, or religious backgrounds co-exist or when one or more of such groups assert its authority over the other. There are several ways of defining hate speech in more specific detail, but the definition below contextualizes the phenomenon of hate speech.

Some definitions of hate speech also explained the concept to embrace messages that cause an atmosphere of discrimination and bigotry - this line of thought assumes that hate speech may cause bias, hostility and violent attacks later on. (Defyhate, 2017). The 
International Covenant on Civil and Political Rights (ICCPR, 2015) UN agreement calls on national governments to prevent hate speech. Article 20(2) says: "any encouragement of nationwide, tribal or religious hatred that represents provocation to inequity, aggression or brutality shall be banned by law." While defining hate speech provides a basis for understanding the phenomenon, how the concept is used in a given situation, in a particular society and at a specific point in time is also pertinent to this discourse. A broad understanding of the socio-political and socio-economic milieu in which hate speech behavior or act occurs should also complement an examination of the speaker and audience to gauge the likely impact of the discourse fully.

\section{Empirical Literature Review}

A study titled "New Media Technologies and Hate messages: Investigating the role of social media in the spread of hate speech in Kenya" was carried out by (Mwongela, 2015a). He sought to examine the use of online platforms in the proliferation of dangerous speech in Kenya to determine the existence of offensive content on the platforms. The goal was to explore the nature of such hate speech and also assess the extent to which users were exposed to hate content among themselves as well as monitor the flow and spread of such hate content online.

The study revealed that hate messages are endemic in the social media sphere, of which $55.9 \%$ were focused on ethnic hatred; $50.2 \%$ were directed at political hate leaving $34.3 \%$ to religious hate (Mwongela, 2015b). He recommended the introduction of curriculum on hate speech at the primary level of education and creative campaigns to advocate for behavioral change as well as endorse penalties and strengthen policies to deal with transmitters of hate speech on the mainstream and social media space. He also suggested more studies that may be required to bridge the academic gap as well as constitute practical solutions to mitigate the spread of hate speech.

Kisilu (2014), in his research titled "How the Youth Used Social Media to Spread Ethnic Hate Speech During the 2013 Presidential Election in Kenya," sought to examine the impact of social media in compounding online ethnic wars among Kenyan youth as well as considering ways they employed social media in the spread of divisive political propaganda during the general elections. Kisilu (2014) also examined ways of curbing online hate speech among Kenyan youths. Her findings revealed that youth are not the only defaulters in propagating hate speech during elections as politicians were guilty through their careless use of hate speech, prompting the younger ones to follow in their footsteps via social media. Kisilu (2014) recommended that politicians should apply caution during electoral campaigns to avoid misleading the youths.

Ezeibe (2015) carried out a research titled "Hate Speech and Electoral Violence in Nigeria" to explore the effects of hate messages on election and aftermath of election violence in Nigeria. His study makes the argument that hateful words in Nigeria arise from partisan leaders and their district, religious or ethnic-based followers, adding that most of these leaders often ignore the provocative propensities of hate messages as long as it allows them to attain and keep political influence. Ezeibe (2015) observes that hate speech has been adopted as a political campaign strategy, which invariably accounts for violence that characterizes election in Nigeria. The study recommended that the Independent National Electoral Commission (INEC) and the society should recognize and prosecute defaulters who propagate hate speech as speaking loudly against hate speech has proved ineffective.

\section{Theoretical Framework}

This research used two media theories to explore how individuals use or interact with the media.

\section{Technological Determinism Theory}

Marshall McLuhan propagated this theory in the year 1962. He posited that technology is a powerful force with the ability to shape human interaction and create social change. He believed that the human lifestyle is highly dependent on the way people process data. Therefore, technological advancement in history or change has been dependent on how people perceive themselves and the world around them. McLuhan (1962) predicted that the world would gradually become a 'global village' where technological advancements would automatically drive human actions and social interactions, and people would be forced to adopt a new wave of social experience prompted by the Industrial Age as opposed to their lifestyle. He indicated that people, organizations, and nations would be connected worldwide via their participation in smaller communities using technology. The theory focuses on the influence of information communication technologies (ICTs) on society and how its effect is unfathomable.

This theory expounds the idea that the internet has greatly influenced the way people interact with one another. People can read and share more information, unlike in the era when traditional media had control of information flow. With technological advancement and proliferation of social media platforms, people can join several platforms and groups. Advancement in mobile phones technology, for example, has also seen the birth of citizens' journalism. People can report, write, shoot videos with their mobile phones and upload them online. Such news travels faster, reaching millions of people worldwide than traditional news channels. People can now share more of same messages across different online platforms. Technology through online social media technology helped to spread different political and ideological beliefs. This had a profound effect on the Nnamdi Kanu-led agitation for Biafra while it last from 2013 - 2017.

\section{Uses and Gratification Theory}

Propounded by Blumler \& Katz (1974) the theory explains the correlation between the media and its audience. It posits that individuals choose and use the media to fulfill their unique needs, and this may include several reasons ranging from the need to acquire knowledge, for humor, to identify with certain groups with mutual interests or to divert themselves from life issues (Oliver \& Nabi, 2009). Similarly, Blumler developed four categories in which people may use the media, and they involve escapism; development of personal relationships; personal identity, surveillance and value bolstering, Katz focused their usage on motives such as cognition, social integration, and sentiments (Peirce, 2007).

Studies from various scholars have proven that the audience is entirely reliant on the media to make individual decisions in line with their innate and social desires. According to Perse (2014), audience gratification can be obtained from sources such as exposure to the media, media content, and the social context in which a person is exposed to the media. That indicates that the people choose a medium based on their needs, and as a result, they will subconsciously consume messages that are in line with their cognitive processes.

In this study, Katz's inquiry on what online audience use the media to do is very relevant given that Nigerians have now found social media platforms such as Facebook to vent and share their opinions and rally other Nigerians to get involved and share their views. In the case of hate speech proliferation and inciting ethnic 
bigotry during the agitation or Biafra, both the supporters and those against used Facebook to satisfy their needs to hold differing opinions on issues of concern to them.

The advent of social media has met the need for networking and interaction of diverse users and audiences. Social media platforms such as Facebook have become channels that are promoting interactions among people of different backgrounds. During the Biafra agitation (2013-2017), pro and anti-Biafra groups and individuals easily interacted with one another online. They voiced their views and opinions on different political beliefs.

\section{Methodology}

This exploratory research adopted both qualitative and quantitative research design. A qualitative research methodology was chosen because of its capacity to produce detailed data and in-depth knowledge of a particular occurrence. While the quantitative study is more numerical, the qualitative method provided additional data which allowed a framework of data collection methods for example key informative content analysis (Silverman, 2005; Baxter 2003) that gave an in-depth analysis understanding of hate messages disseminated through Facebook in the course of the

\section{Data Presentation}

Biafra agitation. The population of this study consists of 313, 333 people living in Ikeja. For this research, Taro Yamane (1967)'s formula was used to arrive at the sample size of 400 registered Facebook users who were purposively sampled in Ikeja. They were all administered with a structured questionnaire that was divided into four sections: (A, B, C, and D), which were designed to address the objectives of this research. Also, it used the five-point Likert response scale (which is often used to measure attitude) with its codes ranging from 1-5; Strongly disagree $=1$, Disagree $=2$, Neutral $=3$, Agree $=4$ and Strongly Agree $=5$.

Also, content analysis was applied in this study to measure and study the existence, relationships, and meanings of certain concepts, words, and themes of 20 hate messages posted on Facebook by pro and anti-Igbo supporters. The analysis covers; hate messages on Facebook that attack pro-Biafra agitators as result of the agitation for Biafra, hate messages on Facebook directed at people of other ethnic backgrounds as a result of their opposition to the agitation for Biafra.

In the end, the quantitative data were analyzed using frequency count and a simple percentage distribution contained in the SPSS 20 application. While for the qualitative data, the contents were analyzed, interpreted, and transcribed. They have been used to back up the presented qualitative results.

Table 1: Awareness and exposure of Facebook users in Ikeja to hate messages during the agitation for Biafra (2013-2017)

\begin{tabular}{|c|c|c|c|}
\hline Item & Response & Frequency & Percentage (\%) \\
\hline \multirow[t]{6}{*}{ I use my Facebook regularly } & Strongly disagree & 28 & 7.2 \\
\hline & Disagree & 60 & 15.5 \\
\hline & Neutral & 99 & 25.6 \\
\hline & Agree & 89 & 23.0 \\
\hline & Strongly Agree & 111 & 28.7 \\
\hline & Total & 387 & 100.0 \\
\hline \multirow{6}{*}{$\begin{array}{l}\text { I have friends and followers from different ethnic groups on } \\
\text { Facebook }\end{array}$} & Strongly disagree & 5 & 1.3 \\
\hline & Disagree & 24 & 6.2 \\
\hline & Neutral & 84 & 21.7 \\
\hline & Agree & 86 & 22.2 \\
\hline & Strongly Agree & 188 & 48.6 \\
\hline & Total & 387 & 100.0 \\
\hline \multirow{6}{*}{$\begin{array}{l}\text { Facebook was used to spread hate messages during the } \\
\text { Nnamdi Kanu IPOB led agitation for Biafra between } 2013 \text { and } \\
2017\end{array}$} & Strongly disagree & 27 & 7.0 \\
\hline & Disagree & 64 & 16.5 \\
\hline & Neutral & 116 & 30.0 \\
\hline & Agree & 60 & 15.5 \\
\hline & Strongly Agree & 120 & 31.0 \\
\hline & Total & 387 & 100.0 \\
\hline \multirow{6}{*}{$\begin{array}{l}\text { Facebook was used by Nigerians to attack themselves based on } \\
\text { their ethnic origins during the agitation for Biafra }\end{array}$} & Strongly disagree & 63 & 16.3 \\
\hline & Disagree & 9 & 2.3 \\
\hline & Neutral & 75 & 19.4 \\
\hline & Agree & 80 & 20.7 \\
\hline & Strongly Agree & 160 & 41.3 \\
\hline & Total & 387 & 100.0 \\
\hline \multirow[t]{6}{*}{ Facebook users use their profiles to attack other ethnic groups } & Strongly disagree & 17 & 4.4 \\
\hline & Disagree & 42 & 10.9 \\
\hline & Neutral & 98 & 25.3 \\
\hline & Agree & 146 & 37.7 \\
\hline & Strongly Agree & 84 & 21.7 \\
\hline & Total & 387 & 100.0 \\
\hline \multirow[t]{6}{*}{ Facebook was used to attack Igbo ethnic groups } & Strongly disagree & 2 & 0.5 \\
\hline & Disagree & 31 & 8.0 \\
\hline & Neutral & 33 & 8.5 \\
\hline & Agree & 290 & 74.9 \\
\hline & Strongly Agree & 31 & 8.0 \\
\hline & Total & 387 & 100.0 \\
\hline Facebook was used by Igbo ethnic origin to attack other & Strongly disagree & 31 & 8.0 \\
\hline \multirow[t]{3}{*}{ Nigerian ethnic groups } & Disagree & 46 & 11.9 \\
\hline & Neutral & 4 & 1.0 \\
\hline & Agree & 41 & 10.6 \\
\hline
\end{tabular}




\begin{tabular}{|c|c|c|c|}
\hline & $\begin{array}{l}\text { Strongly Agree } \\
\text { Total }\end{array}$ & $\begin{array}{l}265 \\
\mathbf{3 8 7} \\
\end{array}$ & $\begin{array}{l}68.5 \\
\mathbf{1 0 0 . 0}\end{array}$ \\
\hline \multirow{6}{*}{$\begin{array}{l}\text { I joined some Facebook groups because members come from } \\
\text { my ethnic origin }\end{array}$} & Strongly disagree & 140 & 36.2 \\
\hline & Disagree & 79 & 20.4 \\
\hline & Neutral & 71 & 18.3 \\
\hline & Agree & 78 & 20.2 \\
\hline & Strongly Agree & 19 & 4.9 \\
\hline & Total & 387 & 100.0 \\
\hline \multirow{5}{*}{$\begin{array}{l}\text { I know a Facebook group that is exclusively created based on } \\
\text { ethnic origin }\end{array}$} & Disagree & 32 & 8.3 \\
\hline & Neutral & 69 & 17.8 \\
\hline & Agree & 82 & 21.2 \\
\hline & Strongly Agree & 204 & 52.7 \\
\hline & Total & 387 & 100.0 \\
\hline \multirow{6}{*}{$\begin{array}{l}\text { Some Facebook groups do not accept other Nigerians that are } \\
\text { not from their ethnic groups }\end{array}$} & Strongly disagree & 11 & 2.8 \\
\hline & Disagree & 34 & 8.8 \\
\hline & Neutral & 103 & 26.6 \\
\hline & Agree & 159 & 41.1 \\
\hline & Strongly Agree & 80 & 20.7 \\
\hline & Total & 387 & 100.0 \\
\hline \multirow{6}{*}{$\begin{array}{l}\text { I have read Facebook messages shared by Hausa-Fulani or } \\
\text { Yoruba friends where they attack Igbos }\end{array}$} & Strongly disagree & 54 & 14.0 \\
\hline & Disagree & 22 & 5.7 \\
\hline & Neutral & 75 & 19.4 \\
\hline & Agree & 97 & 25.1 \\
\hline & Strongly Agree & 139 & 35.9 \\
\hline & Total & 387 & 100.0 \\
\hline \multirow{6}{*}{$\begin{array}{l}\text { I have read messages on Facebook from persons of Igbo origin } \\
\text { attacking persons of Hausa-Fulani or Yoruba ethnic origin }\end{array}$} & Strongly disagree & 35 & 9.0 \\
\hline & Disagree & 73 & 18.9 \\
\hline & Neutral & 99 & 25.6 \\
\hline & Agree & 105 & 27.1 \\
\hline & Strongly Agree & 75 & 19.4 \\
\hline & Total & 387 & 100.0 \\
\hline
\end{tabular}

Table 2: The diffusion of hate messages through Facebook among users in the period under review

\begin{tabular}{|c|c|c|c|}
\hline Item & Response & Frequency & Percentage (\%) \\
\hline \multirow{6}{*}{$\begin{array}{l}\text { Facebook status updates and walls were used to post hate } \\
\text { messages }\end{array}$} & Strongly disagree & 49 & 12.7 \\
\hline & Disagree & 64 & 16.5 \\
\hline & Neutral & 83 & 21.4 \\
\hline & Agree & 81 & 20.9 \\
\hline & Strongly Agree & 110 & 28.4 \\
\hline & Total & 387 & 100.0 \\
\hline \multirow{6}{*}{$\begin{array}{l}\text { I know of Facebook groups where members post hate } \\
\text { messages to attacking other ethnic groups }\end{array}$} & Strongly disagree & 63 & 16.3 \\
\hline & Disagree & 75 & 19.4 \\
\hline & Neutral & 49 & 12.7 \\
\hline & Agree & 163 & 42.1 \\
\hline & Strongly Agree & 37 & 9.6 \\
\hline & Total & 387 & 100.0 \\
\hline \multirow{6}{*}{$\begin{array}{l}\text { Facebook status updates were used to attack people's ethnic } \\
\text { origin }\end{array}$} & Strongly disagree & 53 & 13.7 \\
\hline & Disagree & 47 & 12.1 \\
\hline & Neutral & 104 & 26.9 \\
\hline & Agree & 63 & 16.3 \\
\hline & Strongly Agree & 120 & 31.0 \\
\hline & Total & 387 & 100.0 \\
\hline \multirow{5}{*}{$\begin{array}{l}\text { Facebook videos promote hate speech against certain groups } \\
\text { in Nigeria }\end{array}$} & Disagree & 75 & 19.4 \\
\hline & Neutral & 111 & 28.7 \\
\hline & Agree & 153 & 39.6 \\
\hline & Strongly Agree & 48 & 12.4 \\
\hline & Total & 387 & 100.0 \\
\hline \multirow{6}{*}{$\begin{array}{l}\text { People often repost hate messages seen in groups and personal } \\
\text { walls }\end{array}$} & Strongly disagree & 32 & 8.3 \\
\hline & Disagree & 42 & 10.9 \\
\hline & Neutral & 72 & 18.6 \\
\hline & Agree & 175 & 45.2 \\
\hline & Strongly Agree & 66 & 17.1 \\
\hline & Total & 387 & 100.0 \\
\hline \multirow{5}{*}{$\begin{array}{l}\text { I have read long notes that encourage hatred against the Igbos } \\
\text { and vice versa }\end{array}$} & Strongly disagree & 133 & 34.4 \\
\hline & Disagree & 73 & 18.9 \\
\hline & Neutral & 91 & 23.5 \\
\hline & Agree & 39 & 10.1 \\
\hline & Strongly Agree & 51 & 13.2 \\
\hline
\end{tabular}




\begin{tabular}{llll} 
& Total & $\mathbf{3 8 7}$ & $\mathbf{1 0 0 . 0}$ \\
\hline Facebook users post hate messages on their walls & Strongly disagree & 39 & 10.1 \\
& Disagree & 55 & 14.2 \\
& Neutral & 84 & 21.7 \\
& Agree & 138 & 35.7 \\
& Strongly Agree & 71 & 18.3 \\
& Total & $\mathbf{3 8 7}$ & $\mathbf{1 0 0 . 0}$ \\
\hline My friends share hate messages that attack other ethnic groups & Strongly disagree & 113 & 29.2 \\
on their Facebook profiles & Disagree & 90 & 23.3 \\
& Neutral & 82 & 21.2 \\
& Agree & 39 & 10.1 \\
& Strongly Agree & 63 & 16.3 \\
Facebook links and instant articles promote hate messages & Total & $\mathbf{3 8 7}$ & $\mathbf{1 0 0 . 0}$ \\
& Strongly disagree & 86 & 22.2 \\
& Disagree & 25 & 6.5 \\
& Neutral & 99 & 25.6 \\
& Agree & 125 & 32.3 \\
\end{tabular}

Table 3: Other channels used in the propagation of hate messages during the agitation for Biafra besides Facebook

\begin{tabular}{|c|c|c|c|}
\hline Item & Response & Frequency & Percentage (\%) \\
\hline \multirow{6}{*}{$\begin{array}{l}\text { Social media platforms were generally used to spread hate } \\
\text { speech during the agitation for Biafra }\end{array}$} & Strongly disagree & 48 & 12.4 \\
\hline & Disagree & 49 & 12.7 \\
\hline & Neutral & 63 & 16.3 \\
\hline & Agree & 114 & 29.5 \\
\hline & Strongly Agree & 113 & 29.2 \\
\hline & Total & 387 & 100.0 \\
\hline \multirow{6}{*}{$\begin{array}{l}\text { Whatsapp messages spread hate messages and fear about other } \\
\text { ethnic groups }\end{array}$} & Strongly disagree & 73 & 18.9 \\
\hline & Disagree & 40 & 10.3 \\
\hline & Neutral & 70 & 18.1 \\
\hline & Agree & 62 & 16.0 \\
\hline & Strongly Agree & 142 & 36.7 \\
\hline & Total & 387 & 100.0 \\
\hline \multirow[t]{6}{*}{ Youtube videos promote hate messages during Biafra agitation } & Strongly disagree & 79 & 20.4 \\
\hline & Disagree & 100 & 25.8 \\
\hline & Neutral & 29 & 7.5 \\
\hline & Agree & 116 & 30.0 \\
\hline & Strongly Agree & 63 & 16.3 \\
\hline & Total & 387 & 100.0 \\
\hline \multirow{6}{*}{$\begin{array}{l}\text { Audio messages preach hate against ethnic groups during the } \\
\text { agitation for Biafra }\end{array}$} & Strongly disagree & 62 & 16.0 \\
\hline & Disagree & 69 & 17.8 \\
\hline & Neutral & 95 & 24.5 \\
\hline & Agree & 32 & 8.3 \\
\hline & Strongly Agree & 129 & 33.3 \\
\hline & Total & 387 & 100.0 \\
\hline \multirow{6}{*}{$\begin{array}{l}\text { Twitter was used to spread hate messages during the agitation } \\
\text { for Biafra }\end{array}$} & Strongly disagree & 39 & 10.1 \\
\hline & Disagree & 93 & 24.0 \\
\hline & Neutral & 75 & 19.4 \\
\hline & Agree & 138 & 35.7 \\
\hline & Strongly Agree & 42 & 10.9 \\
\hline & Total & 387 & 100.0 \\
\hline \multirow{6}{*}{$\begin{array}{l}\text { Instagram messages preach hate speech against people of other } \\
\text { ethnic groups }\end{array}$} & Strongly disagree & 50 & 12.9 \\
\hline & Disagree & 68 & 17.6 \\
\hline & Neutral & 84 & 21.7 \\
\hline & Agree & 13 & 3.4 \\
\hline & Strongly Agree & 172 & 44.4 \\
\hline & Total & 387 & 100.0 \\
\hline
\end{tabular}

\section{Discussion of Findings}

The analysis of findings is presented thematically according to the research questions.

RQ1: To what extent were Facebook users aware of and exposed to hate messages in Ikeja during the Biafran agitation 2013-2017?

In table 1, the research found out that the level of Facebook users awareness and exposure to hate messages in Ikeja during the
Biafran agitation between 2013 and 2017 was high because the users in Ikeja visit Facebook regularly. According to the Uses and Gratification theory, individuals use it frequently because it fulfills a particular need in their lives. This correlates with the findings of Martin (2017) that Facebook was ranked as first most visited website globally and as the most popular website worldwide amassing 1.4 billion daily users for December 2017 and 2.13 billion monthly frequent users as of December 31, 2017. Apart from this, the rate at which users in Ikeja visited Facebook daily 
which the research considered as "regularly," can be further explained in the findings of Martins (2017) which shows that more than half of them visit Facebook every day and spend about 20 minutes averagely daily. Table 1 further suggests that the people in Ikeja were aware and exposed to the hate messages during the Biafran agitation between 2013 and 2017 because they visited Facebook every day and spent nothing less than an average of 20minutes.

Furthermore, the research was able to explain why Facebook users in Ikeja visit Facebook regularly. The reason for their regular visit to the platform was because they have friends and followers on Facebook that come from other ethnic groups. That is in line with the technological dynamism theory, which explained that the world would gradually become a 'global village' where technological advancements would automatically drive human actions and social interactions. According to Walther et al., (2008), after inputting their profile, users are encouraged to seek out other Facebook users who they can also send a request. That enables the user to navigate the networks by surfing a list of potential friends' profiles from various parts of the world. By so doing, the user's friends will rise very quickly on Facebook. It is the rise in user's friend that accounted for the easy and quick spread of hate speech. As technological determinant theory posits, advancement in technology will change how people perceive themselves and the world around them, which will eventually result in changes. The research found out that during the Nnamdi Kanu's IPOB-led agitation for Biafra between 2013 and 2017, Facebook was used to spread hate messages. That supports the findings of Jamieson (2009) and Simon Wiesenthal Center (2012) that with the arrival of Facebook, hate speech has increased and hate groups have also added the platform as a channel of communication to spread hate messages. Generally, Facebook was used as a platform for spreading hate speech during the Biafran agitation between 2013 and 2017. This conclusion is drawn from the analysis of over 30 different Facebook post and comments that were reviewed in this research. Some analysis of hate messages were on Facebook profile, comments, and group chats, etc. Some of the posts include:

\section{We are expecting ur worse all igbos in in Abuja, Lagos ,Kaduna, Ibadan we kill them all before we progress to that ur biafra land.My wife is from IMO and I will kill her first,mumu people.}

\section{https://Www.facebook.com/profile.php..}

FB/Profile/ Adebiyi/01

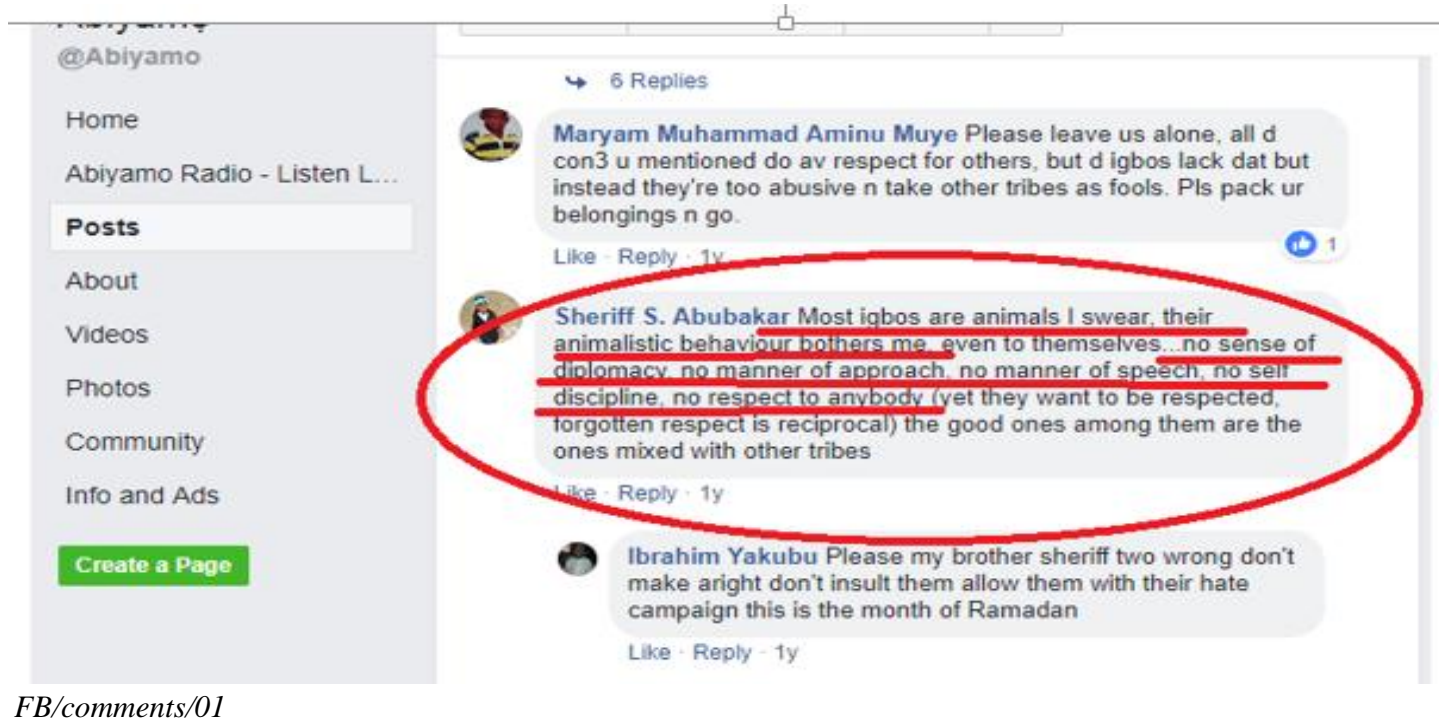

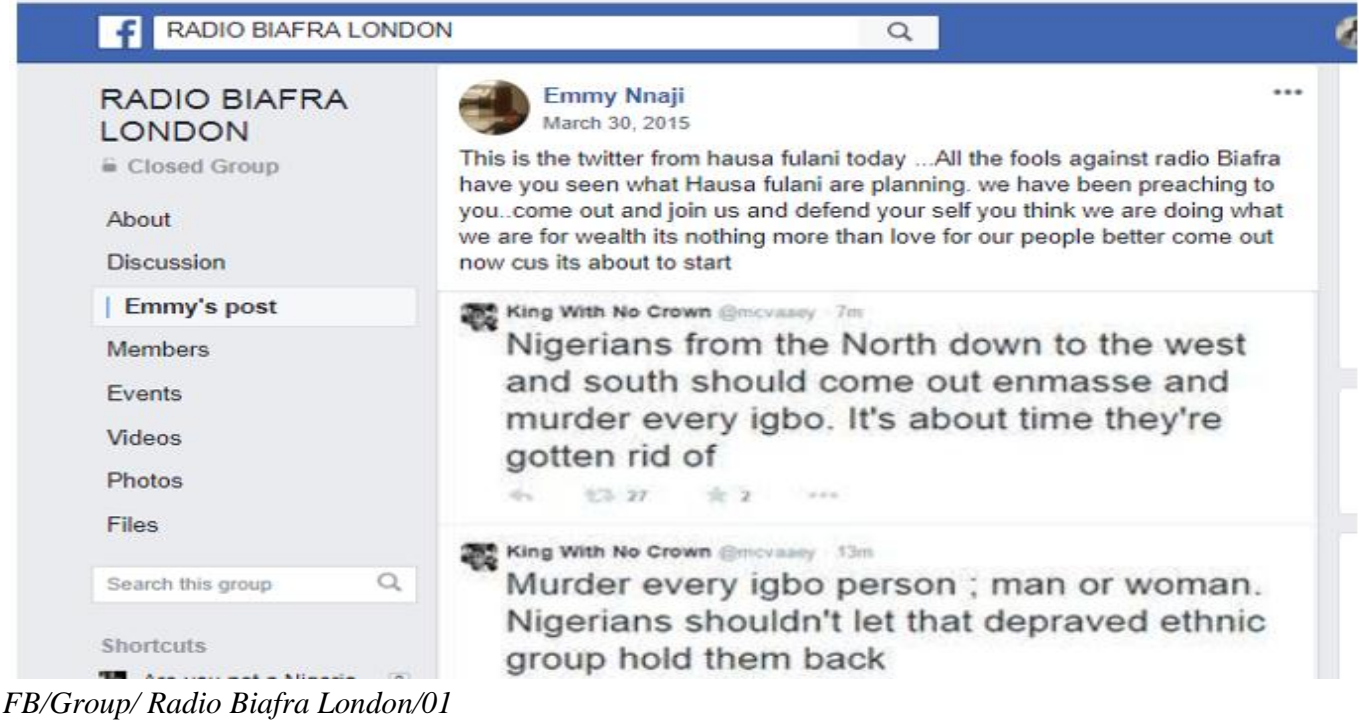


It was also used by Nigerians to attack themselves based on their ethnic origins during the agitation for Biafra. That corroborates the position of Technological Determinism theory that people, organizations, and nations would be connected worldwide via their participation in smaller communities using technology such as Facebook.

It is instructive to note that the hate messages disseminated through Facebook that during the Biafran agitation was based mainly on ethnic sentiments which corroborates the view of Elliot et al., (2016), that hate speeches transmit messages that justify bigotry, racism, prejudice or other types of hate, including xenophobia and resentment towards people of minority and immigrant origin. Some Facebook posts analyzed further for greater insight:

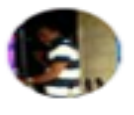

Durosinmi Ibrahim shared a post.

June $11,2017 \cdot 9$

\begin{abstract}
Igbo's are useless people. They II stay in lagos and call for Biafra. Y can they go and livre and developed Biafra. They are scatter all over west African. They are not proud of they region. All Igbo's should go and developed Biafra. Period. All the bad things started in Igbo land. Kidnapped of human been for ransom started in Igbo land
\end{abstract}

FB/post/01

This post shows that the author is not from Igbo ethnic origin. The name "Durosinmi Ibrahim" suggests that the author is from the Yoruba ethnic group. Besides, the first sentence indicates that the message is a direct attack on the Igbos: "all the bad things started in Igbo land," which shows that hate speech and stereotypes were directed towards individuals from different ethnic origins during the agitation for Biafra.

Apart from the hate speech that labels groups of people, Facebook users in Ikeja were aware that people use their profiles to spread hate messages, which makes it possible to identify such individual with the hate speech. It also supports the findings of the
National Stability and Reconciliation Programme's report on Mitigating Hate Speech Online (NSRP, 2017) that 76 percent of dangerous messages monitored online are communicated via Facebook, either as updates on an individual's profile page or in group chats. Isaac (2017) cited an example of a Nigerian police officer named Salihu Ajanaku, who took to Facebook to spread hateful messages against the Igbo ethnic group origin.

In addition to the result of the quantitative data that found out that people in Ikeja were aware that Facebook was used to attack the Igbo ethnic group, the data gathered on Facebook also support these findings. Some Facebook post shows that:

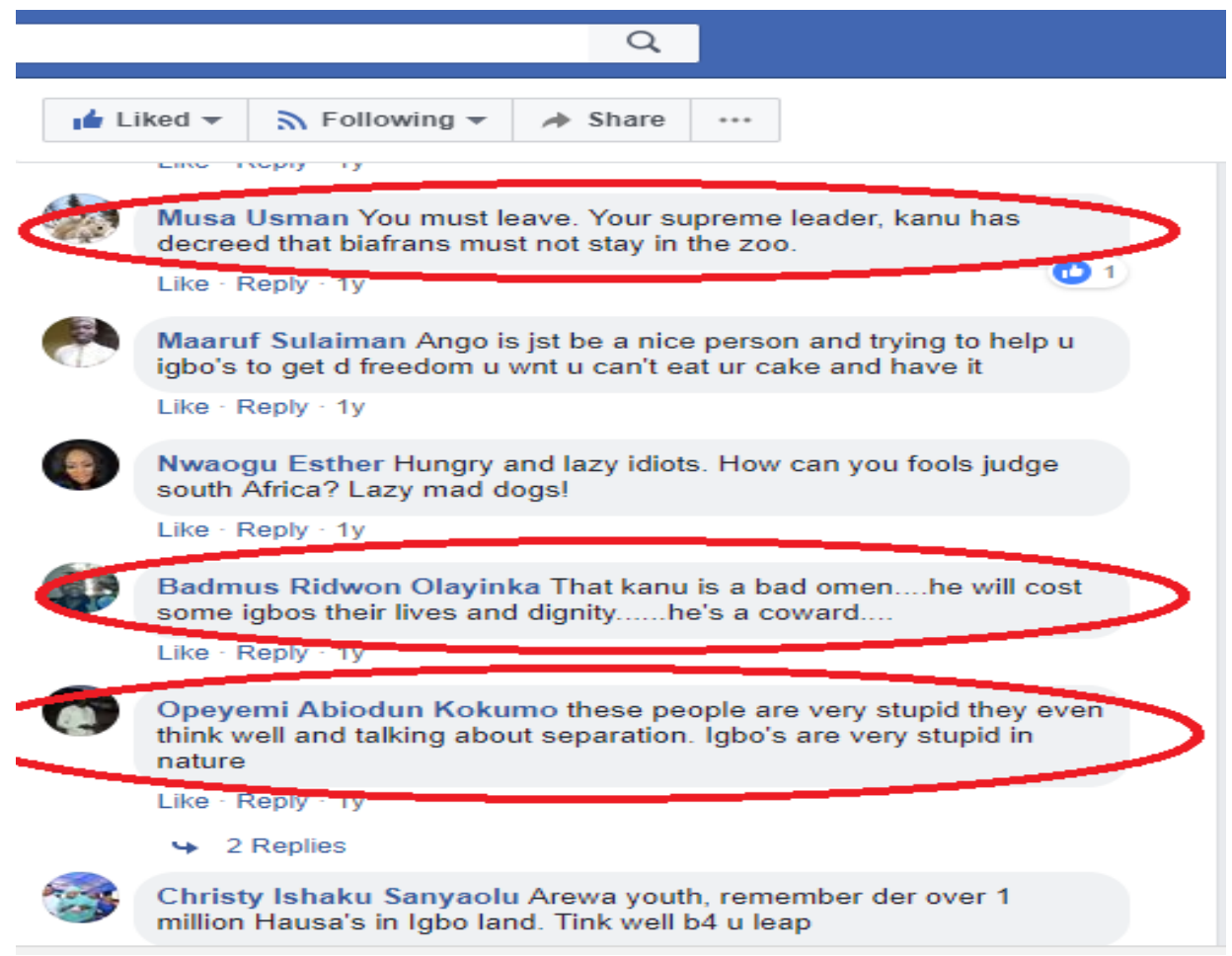

FB/post/02

This post showed that Facebook was used to attack the Igbo ethnic group. All three posts showed that Facebook was used to attack the Igbo ethnic group. All the comments were more of hate speech. For instance, the first highlighted comment, which was a post from a northerner suggests that the Igbos must leave (vacate) the northern part of Nigeria as demanded by the AREWA youth group.
Similarly, the second highlighted post indicates that the Yoruba man was directly attacking the IPOB leader who he referred to as a coward. That by implication means that he was not only calling the leader a coward but indirectly referring to the entire ethnic group as cowards. Lastly, the third post, which was also made by another Yoruba, directly attacked the Igbos by calling them "stupid." Even 
though some of the posts on Facebook during this period were mere appeals as in the second post and the last post or reaction from the Igbos as in the case of the third post, it appears that three out of every six Facebook offensive posts were attacking the Igbos. Therefore, one can assume that the majority of the hateful posts on Facebook during this period were direct attacks on the Igbos.
Even though the hate messages by other ethnic groups attacked the Igbos, it is still important to note that the Igbos were also attacking different ethnic groups. The research found out that the people in Ikeja were aware that the Igbos used Facebook to attack other Nigerians. A Facebook post showed that:

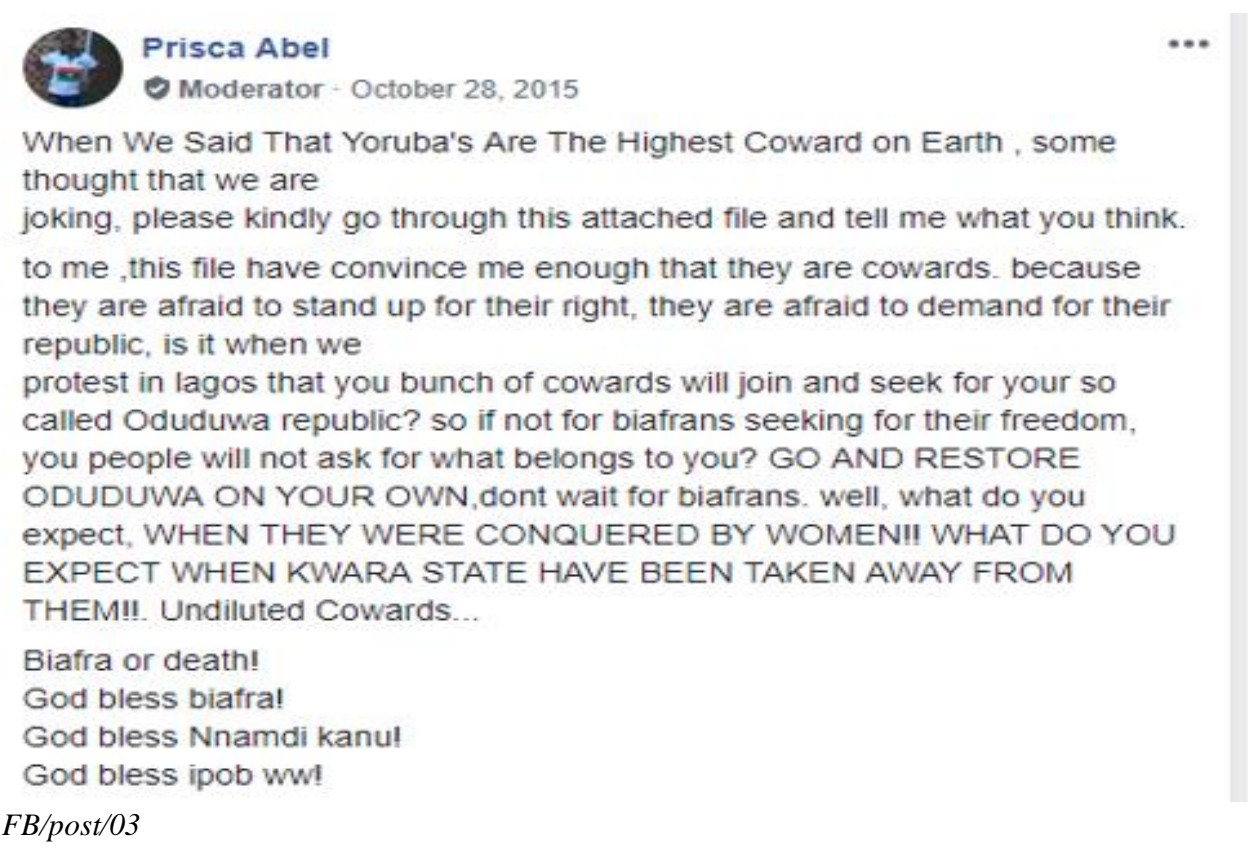

This post came amid the agitation for the actualization of Biafra was between 2013 and 2017. The post suggests that this young Igbo indigene was directly attacking the Yorubas. He noted that the inability of the Yoruba's to fight for their nation is an indication of cowardice. Similarly, another related post shows the way the Igbos attacked the Hausas.

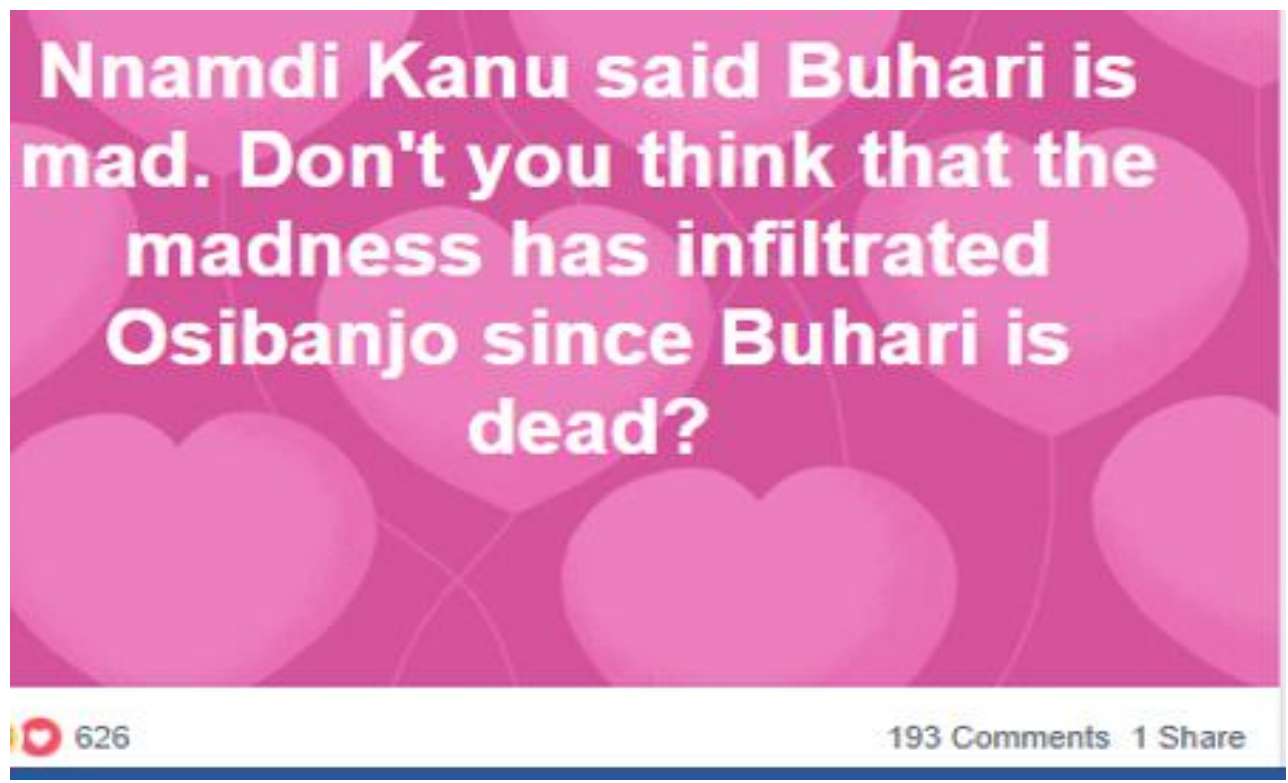

FB/post/04

This particular post was a direct attack on the leading figures of both the Hausas and the Yorubas in Nigeria. This findings still supported the video posted on Radio Biafra where Nnamdi Kalu described the "Yorubas as worse than Boko Haram." The way the various groups used Facebook, therefore, agrees with views of the Uses and Gratification theory explained in this study, which correlates with the position of Nabi \& Oliver (2009) that individuals choose and use the media to fulfill their unique needs.
Thus, most of the ethnic groups are using Facebook to attack other ethnic groups.

However, even though people in Ikeja did not join their Facebook groups based on ethnic affiliation yet, they are not ignorant of the fact that some Facebook groups will not accept a friend request from people outside their ethnic group. This research found out that one of such groups is Radio Biafra London, which is a closed group. 


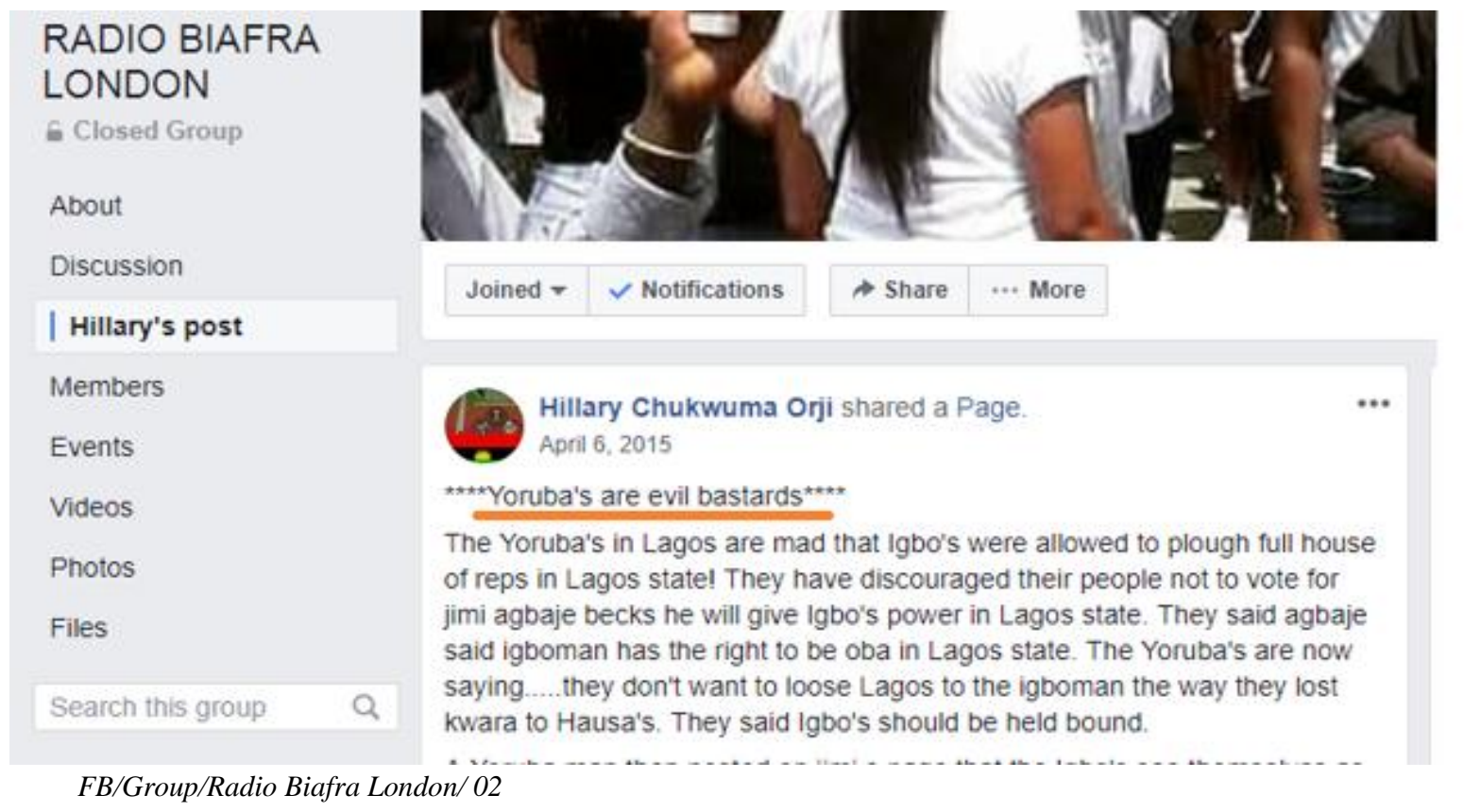

By implication, only those that meet the criteria for joining such groups are accepted because the profile of each applicant is thoroughly examined before their friend request will be considered or even accepted. Based on all this discussion, it is evident that Facebook users in Ikeja were aware and exposed to messages shared by Hausa-Fulani or Yoruba friends wherein they attacked the Igbos and vice versa.
RQ2 How was hate messages propagated through Facebook during the period under review?

In table 2, the research found that hate messages were propagated through Facebook over the Biafran agitation 2013-2017. The study was able to identify six means through which hate speech was spread during the agitation between 2013 and 2017. The first strategy identified was the used of status and wall.

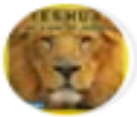 \\ - Odera Chukwuebuka $\$$ RADIO BIAFRA LONDON August 6, 2017 \\ TRANSCRIPT OF THE ANTI-IGBO SONG CALLING FOR GENOCIDE AGAINST NDI IGBO IN THE NORTH
}

\author{
First I want to appeal to Almighty Allah to help me in this song not to \\ deviate, these useless children of thieves and unemployed. Igbos in Nigeria \\ have no sun.
}

\section{Chorus:}

Igbos (Inyamirin) are ungrateful people and fools Igbos are a curse to Nigeria, whose existence and birth as a people in Nigeria is useless, that abortion is greater than the birth of the bastards.

\section{Let's drag and drag and see who will sleep in the sun, Igbo land, in the beginning, has no name, they were helped to get name and identity. And that's the beginning of their trouble.}

\section{FB/Wall/01}

The hate message on this wall was presented as a song. Of course, it could also be presented in other forms such as images, animation, text, etc. The use of Facebook walls, which are private to individuals for the dissemination of hate messages, was reasonably common. For example, a Facebook user such as Odera Chukwuebuka can post comments to on his wall that can be seen by other people on the platform such as those group members of the Radio Biafra London. No matter how brief the messages posted on the walls are, they tend to reveal the feeling among 'friends,' or draw the attention of others from different groups or sites. In this case, Odera Chukuwebuka is drawing the attention of other members of Radio Biafra London to the anti-Igbo song which called for genocide against Igbos.

In addition to using Facebook status and wall, protagonists of hate messages also employed Facebook group chats. One of the prominent groups that were used at this period was Radio Biafra London, which is a closed group. This group allowed only members to see the post of other group members, likewise their comments. Friendship requests for such groups were accepted on conditions such as being a member of the Igbo ethnic group. 


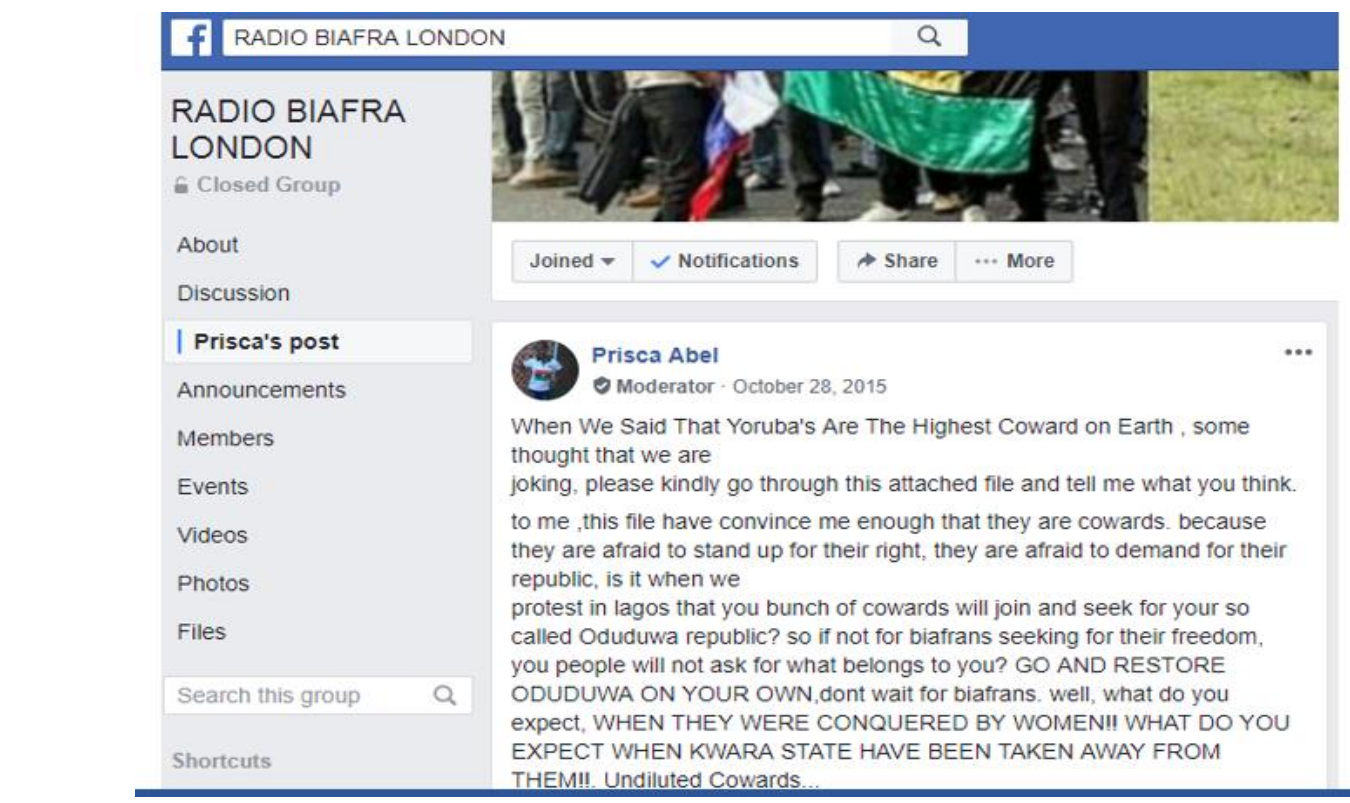

FB/Group/Radio Biafra London/ 02

In this group chat, a particular post attacked the Yorubas. Also, group members also used videos to communicate abusive content which is similar to the Facebook.com/radio Biafra (2017) video post that was shared widely on Facebook, and Radio Biafra Facebook page in which Kanu described the "Yorubas as worse than Boko Haram.

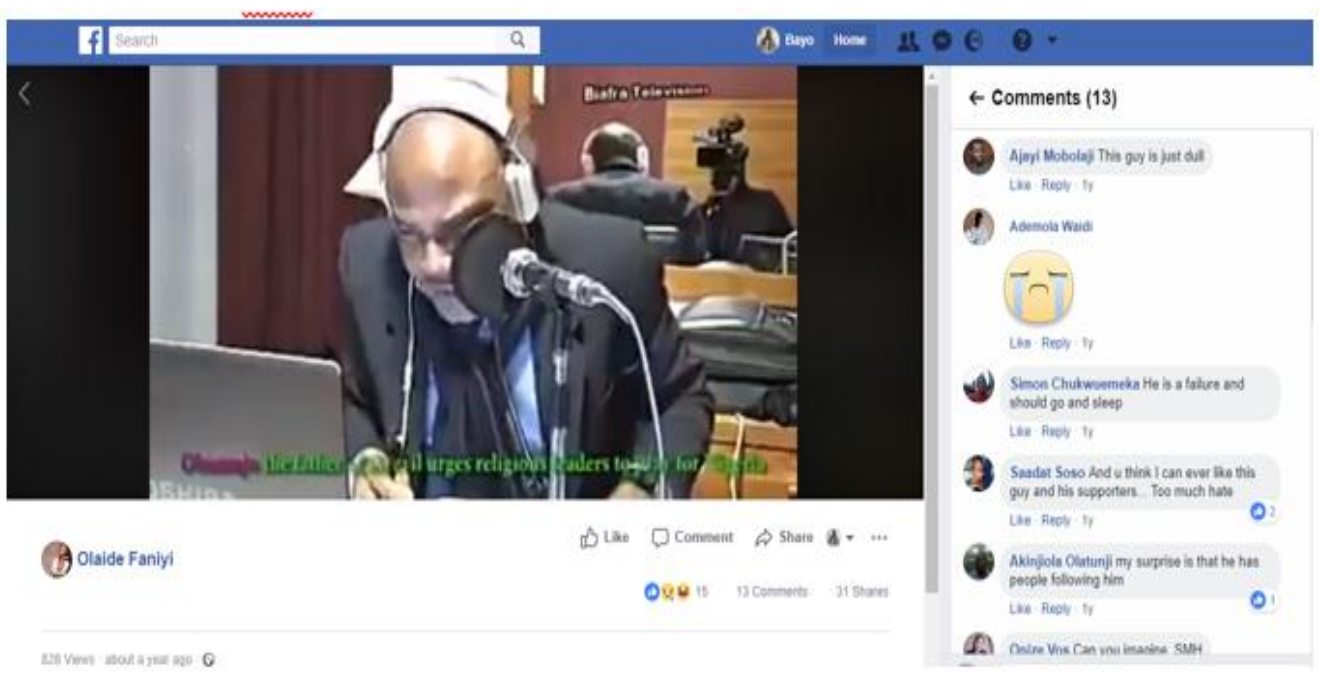

FB/video/

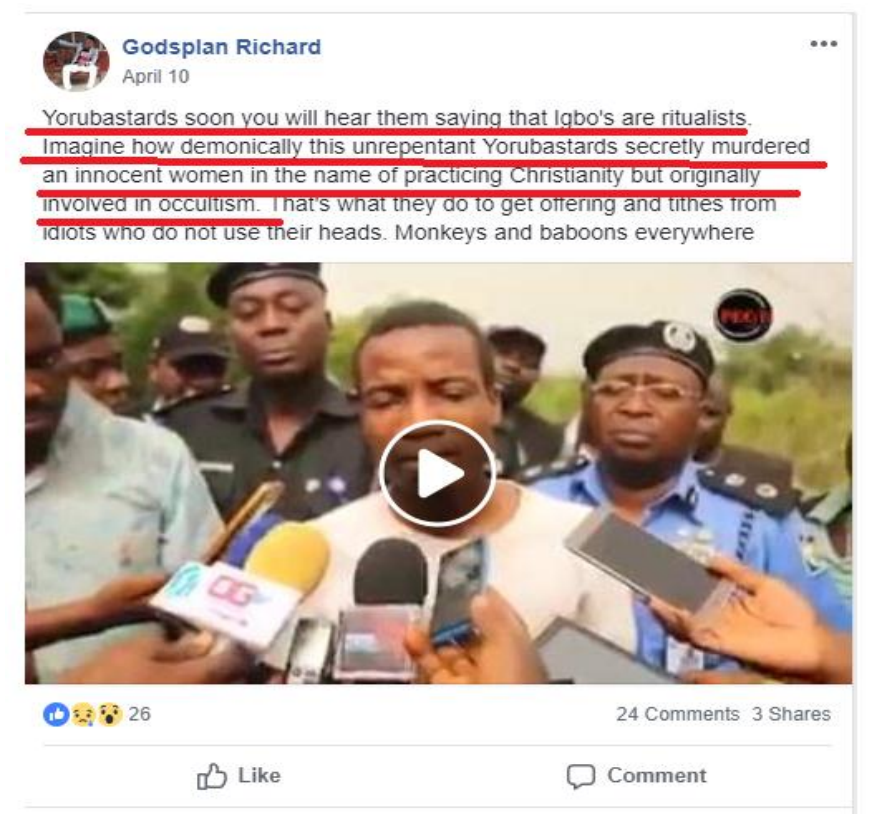


This feature allowed individuals to access audio-visual broadcasts on Biafra agitation. It also allowed various individuals to comment and like, as well as share the video and repost them. The links of these videos, as well as other related articles, were also shared via Facebook

More importantly, the research was able to establish that advances in communication technology enhanced all the six channels through which hate speech was propagated during the agitation between 2013 and 2017. This aligns with the postulation of Technological Determinism theory that technology is a powerful force with the ability to shape human interaction and create social change. Using all these means on Facebook has formed people's perception of the agitation and has also allowed various persons regardless of the distance to access the messages. It correlates Cohen (2000) view that in contemporary society, the notion of fastchanging technologies altering human lives is all-pervasive because it has given people access to a vast volume of information. This support the position of the technological determinism theory that People can read and share information as against the era when traditional media had control of information flow.

RQ 3: What are other platforms that may have contributed to the proliferation of hate speeches during the Biafran agitation other than Facebook?

In table 3, this research found that other social media platforms were used to propagate hate messages during the agitation for Biafra however, apart from Facebook which is the major social media platform that was used to spread hate speech during this agitation, four other social media platforms were also used. They include; Whatsapp, YouTube, Twitter, and Instagram. This corroborated the position of Gillespie, (2010) that these social media platforms play a critical role as a cultural go-between in a given society because of their ability to shape public discourse and determine what constitute free or hate speech. Similarly, it correlates with the Technological Determinism theory that says that information communication technologies (ICTs) influence society and has an unfathomable effect on society. Similarly, Uses and Gratification theory posited that individuals choose and use the media to fulfill their unique needs, including spreading hate speech.

\section{Conclusion}

This study concludes that to a considerable extent Facebook users were aware of and exposed to hate messages in Ikeja during the Biafran agitation between 2013-2017 because most of the users visit the platform regularly and spend a minimum of 20 minutes every day.

However, hate messages were propagated through Facebook during the agitation for Biafra 2013-2017 through six various means. These means include; Facebook status and wall, Facebook groups, Facebook videos, individual comments, and likes, through sharing the video and repost, and links of this videos as well as other related articles. All of these means were used by various individuals from diverse beliefs and affiliations. This finding supports the underlying assumption of the use and gratification theory.

Besides, the research was able to establish that in addition to Facebook, some other social media platforms contributed to the proliferation of hate messages during the agitation for Biafra. The study was able to establish that four additional social media platforms contributed to this; they include; WhatsApp, Youtube, Twitter, and Instagram. Base on the discussion presented above, the research, therefore, concludes that Facebook played a very crucial role in disseminating hate messages over the agitation for Biafra between 2013-2017 in Ikeja.

\section{Recommendations}

Based on the findings and conclusion arrived above, this research makes the following recommendations:

- Social media, most notably Facebook should review their policies as it relates to monitoring hate messages on the platform which guides interactions on groups and individual profiles so that there would be a generally acknowledged standard that would regulate and prevent the dissemination of hate messages on the platform.

- It is crucial that social media platforms set up an effective monitoring system that would be able to detect hate messages and report and remove them immediately so that the right action can be taken on time.

- It is important to educate members of the public on the dangers of hate messages via social media. In line with the position of the Uses and Gratification theory, which explains that people make use of technology for their gain, it is essential to re-orientate people of the dangers involved in using this social medium for the wrong purpose and enlighten them on how they can use the social media platforms such as Facebook to promote national integration.

- The government should put measures in place to regulate the use of social media to check the spread of hate messages. Also, laws to criminalize and punish those who use Facebook and other social media platforms to attack other Nigerians should be enacted to foster peace and harmony in a multiethnic and multi-religious society like Nigeria, where several ethnic conflicts have led to the loss of lives and properties.

\section{Data Availability}

All data generated and analysed are available in this paper

\section{Conflicts of Interest}

The authors declare that there is no conflict of interest regarding the publication of this paper

\section{Funding Statement}

The authors received no financial support for the research, authorship or publication of this article.

\section{References}

1. Blumler, J. G., \& Katz, E. (1974). The uses of mass communications: Current perspectives on gratifications research (Vol. 1974). Sage Publications, Inc.

2. Cohen, J., (2000). More Censorship or Less Discrimination? Sexual Orientation Hate Propaganda in Multiple Perspectives. McGill Law Journal, 46. Retrieved From: http://www.lawjournal.mcgill.ca/userfiles/other/7444196 -Cohen.pdf

3. Defyhatenow. (2016). Introduction to Hate Speech on Social Media. Retrieved from: 
https://defyhatenow.net/wp-

content/uploads/2016/06/defyhatenow_whatishatespeech _JUL27.pdf

4. Elliot, C., Chuma, w., Gendi, D. M., \& Patel, A. (2016).Hate Speech, Key Concept Paper. Retrieved from:

http://eprints.whiterose.ac.uk/117296/1/Elliott\%20etal\% 202016_Hate\%20Speech.pdf

5. Ezeibe, C. C., (2015). Hate speech and electoral violence in Nigeria. Presented at the Two-day National Conference on the 2015 General Elections in Nigeria: The Real Issues held at The Electoral Institute, the INEC Annex, Abuja, Nigeria on 27-29 July 2015.

6. Gillespie, T. (2012, February 22). The Dirty Job of Keeping Facebook Clean. Culture Digital.http://culturedigitally.org/2012/02/the-dirty-jobof-keeping-facebook-clean/

7. Isaac, D., (2017). Nigerians come after police officer for insulting Igbos Retrieved from https://www.pulse.ng/gist/nigerians-come-after-policeofficer-for-insulting-igbos-id7095230.html

8. Jamieson, A., (2009). Facebook "must do more to tackle racism," said campaign groups. The Telegraph. Retrieved from

http://www.telegraph.co.uk/technology/facebook/520542 6/Facebook-

9. Kazeem, Y. (2016). More People use Facebook in Nigeria than anywhere else in Africa. Retrieved from: https://qz.com/611516/more-people-use-facebook-innigeria-than-anywhere-else-in-africa/

10. Kinyamu, M., (2012, 6th December 2012). Eight reasons why companies in Kenya need a Social Media Manager. Retrieved from: http://cio.co.ke/blog/8-reasons-whycompanies-in-kenya-need-a-social-media-manager

11. Kisilu. C. M., (2014). How the Youth Used Social Media to Spread Ethnic Hate Speech During The 2013 General Elections. Retrieved From: https://bit.ly/2Lb7EDE

12. Martin B. (2017, March 6). The Global Digital Future in Focus 2018.comScore Whitepaper. https://www.comscore.com/Insights/Presentations-andWhitepapers/2018/Global-Digital-Future-in-Focus-2018

13. McLuhan, M., (1962). Marshall McLuhan Predicts The Global Village. Retrieved From: https://livinginternet.com/i/ii_mcluhan.htm

14. Mohapi, T., ((2017). Nunu Nntshigla speaks about Facebook growth in Africa and helping businesses meet their goals Retrieved from https://www.iafrikan.com/2017/04/10/nunu-ntshingilaspeaks-about-facebooks-growth-in-afrika-and-helpingbusinesses-meet-their-goals/

15. Molnar, P., (2012). Interview with Kenan Malik. The Content and Context of Hate Speech: Rethinking Regulation and Responses, 81-91.
16. Mwongela K.F (2015a) New Media Technologies and Hate Messages: Investigating the Role of Social Media in Propagation of Hate Messages in Kenya Retrieved from http://erepository.uonbi.ac.ke/bitstream/handle/11295/93 365/Mwongela_New\%20Media\%20Technologies\%20an $\mathrm{d} \% 20 \mathrm{Hate} \% 20 \mathrm{Messages}$.pdf?sequence $=3$

17. Mwongela, K. F. (2015b) A Study on How Social Media Have Changed Newsroom Operations in Kenya: A Case Study of The Standard Group and Nation Media Group. Retrieved From: https://bit.ly/2J19Vop

18. Nabi, R. L., \& Oliver, M. B. (Eds.). (2009). The SAGE handbook of media processes and effects. Sage.

19. National Stability Reconciliation Programme, (2017). Monitoring and countering hate speech to reduce violence Retrieved from http://www.nsrp-nigeria.org/wpcontent/uploads/2017/12/NSRP-How-to-GuideMitigating-Hate-and-Dangerous-Speech.pdf

20. Perse, E. M., (2014). Media Effects, Strength. Retrieved From: http://www.blackwellreference.com/public/tocnode?id=g 9781405131995_yr2015_chunk_g978140513199518_ss3 4-1

21. Pierce, J., (2007). Uses and Gratification theory Retrieved from https://sites.psu.edu/sarahturney/usesand-gratifications-theory/

22. Silverman, D., (2005). Doing Qualitative Research: A Practical Guide. Retrieved from: https://books.google.com.ng/books/about/Doing_Qualitat ive_Research.html?id=gs2yhThw4vMC\&redir_esc=y

23. Simon Wiesenthal Center. (2012). Social Media Must Do More To Thwart Subculture Of Hate Fueling Lone Wolf Terrorism - Simon Wiesenthal Center Debuts 2012 Digital Hate Report. Retrieved From: http://www.wiesenthal.com/site/apps/nlnet/content2.aspx

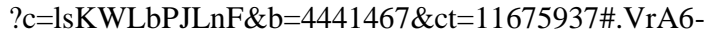
aL89GG

24. Statistica, (2018). Number of daily active Facebook Users Worldwide As of 1st quarter 2018 in millions Retrieved from https://www.statista.com/statistics/346167/facebookglobal-dau/

25. UNHRC (2017), Committee on the Elimination of Racial Discrimination. (n.d). Retrieved From: http://www.ohchr.org/EN/HRBodies/CERD/Pages/CER DIndex.aspx

26. Uwerunonye, N. (2017, April 29). How IPOB Leader, Nnamdi Kanu, became Buhari's

27. Walther, Heide, Kim, Westermann \& Tong (2008). The Role of Friends' Appearance and Behavior on Evaluations of Individuals on Facebook: Are We Known by the Company We Keep? Retrieved from: https://academic.oup.com/hcr/article/34/1/28/4210811 